\title{
WTO Members' Commitments in Education Services
}

\author{
Jian Xu \\ Intensive Language Training Centre, Sichuan University \\ 24 Nanyiduan, Yihuanlu, Chengdu 610065, China \\ E-mail: xujian88@hotmail.com
}

\begin{abstract}
The establishment of World Trade Organization is in line with the conclusion reached at the end of the Uruguay Round in April 1994 by the bulk of the world's trading nations. WTO is in charge of managing multilateral trading system. WTO's "General Agreement on Trade in Services" (GATS) requires member nations to comply with the following basic rules: all member nations equally enjoy Most-Favored-Nation (MFN) treatment; enterprises of other member nations can enjoy equal treatment and market access in one member nation's territory with its domestic enterprises. GATS includes the general agreement, annex and the schedules of commitments. Schedules of commitments is a sort of document which shows the obligations stimulated in the GATS about market access and national treatment that one WTO member nation will fulfill, or that the obligations that one WTO member nation hopes to be exempted from. When a WTO member nation makes a commitment, it has set legally the standards of market access and national treatment in its schedule of commitments, and will no longer introduce any other measures which will limit the market access and national treatment in trade in education services.
\end{abstract}

Keywords: GATS, Horizontal commitments, Specific commitments

\section{The market access and national treatment of education services within the framework of GATS}

The basic principles of WTO cover all of the WTO agreements, constituting the foundation of the multilateral trading system. These principles are: 1. Trade without discrimination; 2. Freer trade: gradually, through negotiation; 3. Predictability: through binding and transparency; 4. Promoting fair competition. The principle of trade without discrimination includes most-favoured-nation treatment (MFN) and national treatment. As an important part of WTO trade in services, international trade in education services, of course, has to comply with the above principles.

AS an important treaty of the World Trade Organization, GATS includes the general agreement, annex and the schedules of specific commitments. Just like in other sectors of trade in services, when WTO member nations are having negotiations about trade in education services, they should make specific commitments in the aspects of market access and national treatment in different sectors of education services, and list them in the schedules of commitments. A specific commitment in education services is an undertaking to provide market access and national treatment for the service activities in education. When making a commitment a WTO member nation binds the specified level of market access and national treatment and undertakes not to impose any new measures that would restrict the market access or the operation of the service in education. Specific commitments thus are a guarantee to the education services or the suppliers of education services of other WTO member nations that the conditions of entry and operation in the market will not be changed to their disadvantage.

Market access in education services means that within the four modes of supply of education services, WTO member nations open their education markets to other member nations, give them favorable treatments which are no less favorable than those clearly defined in the schedules of commitments, and do not take any other restrictive measures. National treatment means that within the sectors of education services that have made commitments, and under the conditions and qualifications which have been committed, one WTO member nation give other member nations the treatments which are no less favorable than the treatments enjoyed by its domestic education services or suppliers of education services.

Schedules of commitments is a sort of document which shows the obligations stimulated in the GATS about market access and national treatment that one WTO member nation will fulfill, or that the obligations that one WTO member nation hopes to be exempted from. When a WTO member nation makes a commitment, it has set legally the standards of market access and national treatment in its schedule of commitments, and will no longer introduce any other measures which will limit the market access and national treatment in trade in education services. 


\section{The main content of commitments in education services}

As has been mentioned before, World Trade Organization divides services into 12 sectors: 1. Business Services; 2. Communication Services; 3. Construction And Related Engineering Services; 4. Distribution Services; 5. Educational Services; 6. Environmental Services; 7. Financial Services; 8. Health Related And Social Services; 9. Tourism And Travel Related Services; 10. Recreational, Cultural and Sporting Services; 11. Transport Services; 12. Other Services Not included Elsewhere. Education services is the fifth of the 12 sectors, and is sub-divided into primary education service, secondary education service, higher education services, adult education service and other education service.

The related provisions of GATS on market access and national treatment are the legal basis on which WTO member nations can make specific commitments in education services. Therefore, the schedules of commitments of individual countries cover the commitments on market access and national treatment with respect to each of the four modes of supply of trade in education services: these are cross-border supply; consumption abroad; commercial presence; and presence of natural persons. That means for each of the four modes of supply of trade in education services, every WTO member nation should list out one by one in its schedule of commitments the restrictive measures it will take on the education services coming from other member nations.

The core part of schedules of commitments in education services is the four modes of supply of trade in education services, as well as the basic requirements of GATS on market access, national treatment and possible additional commitments. "With respect to the four modes of supply of education services, there are three basic ways of making commitments. First, 'no limitations'. That means a WTO member nation has committed not to impose any restrictive measures on the market access and national treatment of foreign suppliers of education services. Second, 'unbound'. That means a WTO member nation retains its control over trade in education services and doesn't assume any obligations, nor makes any commitments. It just acts according to its wishes. Third, 'limitations'. That means a WTO member nation has listed out the details of limitations on market access and national treatment in education services."(Wu, 2004) And with respect to each of the four modes of supply of education services, a WTO member nation has also made specific commitments on market access, national treatment.

WTO requires each member nation to make its own schedule of commitments in education services, and to explain its limitations on market access and national treatment as well as other limitations. In the schedules of commitments, commitments are split into two sections: First, "horizontal" commitments, which set limitations on all of the sectors included in the schedule, especially the two modes of supply of education services--commercial presence and the presence of natural persons. Second, specific commitments apply to a particular sector or subsector of education services. Therefore, horizontal commitments are the basic commitments which apply to all sectors of education services. And specific commitments are further commitments based on the horizontal commitments with respect to specific sectors of education services. They are also the clarification of the specific commitments made with respect to the fore-mentioned four modes of supply of education services. GATS use affirmative way to make commitments. Therefore, only the commitments which are listed in the schedules of commitments need to be carried out. In the sectors of education services with respect to which a WTO member nation has not made any commitments, this member nation can decide independently whether to impose any limitations or not.

If a WTO member nation wishes to take back something it has given in past negotiations, it can modify or withdraw commitments in schedules. But commitments can only be withdrawn or modified after the WTO member nation has reached an agreement of compensatory adjustments with affected member nations, and no withdrawals or modifications may be made until three years after entry into force of the Agreement. In the event that the negotiations do not lead to agreement, any affected WTO member nation which believes it has a right to compensation may take the matter to arbitration.

\section{General introduction of the commitments made by various WTO member nations in education services}

At present, 44 WTO member nations have made commitments on education services. Among them, 32 nations have made commitments on higher education services, and adult education services; 30 nations have made commitments on primary education services; 35 nations have made commitments on secondary education services; 32 nations have made commitments on adult education services; and 20 nations have made commitments on other education services.

Among the thirty-two WTO members that have made commitments on higher education services, seventeen nations have made full commitments on national treatment. There are thirteen nations, which have made commitments on national treatment for Mode 1(Cross-border supply), Mode2 (Consumption abroad), and Mode 3 (Commercial presence). Two nations have made full commitments on market access. Eight nations have made partial commitments on market access. Thirteen nations have made commitments on market access for Mode 1, Mode2, and Mode 3. Only three nations have made full commitments for Mode 4 (Presence of natural persons).

Among the thirty nations that have made commitments on primary education services, seventeen nations have made full commitments on national treatment for Mode 1, Mode2, and Mode 3, and six have made full commitments on national 
treatment for Mode 4. Eight nations have made full commitments on market access for Mode 1, Mode 2, and mode 3. Only nation has made partial commitments on market access and national treatment for Mode 4.

Among the thirty-five nations that have made commitments on secondary education services, nineteen nations have made full commitments on national treatment for Mode 1, Mode2, and Mode 3. Five nations have made full commitments on national treatment for Mode 4. Two nations have made partial commitments on national treatment for Mode 4.Twelve nations have made full commitments on market access for Mode 1, Mode 2, and Mode 3. Two nations have made partial commitments on market access for Mode 4.

Among the thirty-two nations that have made commitments on adult education services, twenty-five nations have made full commitments on national treatment for Mode 1, Mode 2 and Mode 3. Eighteen nations have made full commitments on market access.

Among the 20 nations that have made commitments on other education services, eleven nations have made full commitments on national treatment for Mode 1, Mode 2 and Mode 3. Ten nations have made full commitments on market access for Mode 1, Mode 2 and Mode 3.

In the five sectors of education services, developed countries have made more commitments. And primary and secondary education services have received more limitations than higher education services, adult education services and other educations services. WTO member nations have imposed more limitations on the market access of education services than on national treatment. With respect to the four modes of supply of education services, mode 2 (consumption abroad) has got the most commitments, and mode 4 (presence of natural persons) has got the most limitations.

\section{The impact of WTO members' commitments in education services}

WTO members' commitments in education services upon their entry into WTO will have a major impact on their domestic education services. While facing many challenges, each WTO member's domestic education service industry has also gained a rare opportunity to expand the absorption and introduction of foreign educational resources, and to speed up its development. Under the rules of WTO, foreign suppliers of education services are allowed to enter into every member nation's education market, and each member nation's education service institutions can also go out into the international education market to participate in the competition. Comprehensive and scientific analysis of the impact of WTO members' commitments in education services will help us seize the opportunity and make the initiative. Judging from the commitments in education services made by WTO member nations, we can see that the main impact is on the four modes of supply of education services - "Cross-border Supply, Consumption Abroad, Commercial Presence and Presence of Natural Persons".

\subsection{Cross-border supply}

With respect to cross-border supply, many education materials from foreign suppliers of education

services will enter every WTO member nation's domestic education market, including various types of teaching books, audio-video teaching and learning materials, teaching equipment and computer teaching software. This will have a strong impact on every WTO member nation's textbook publishing industry, audio-video publishing industry, teaching equipment manufacturing enterprises and the software industry. They will have to face the direct competition from foreign education services.

\subsection{Consumption abroad}

With respect to consumption abroad, foreign suppliers of education services will strengthen their contention for each WTO member nation's education market, trying to attract more students to their countries to receive education services. On one hand, massive domestic students' studying abroad has made each WTO member nation, especially developing nations, suffer from loss of talents and outflow of capital and has had a great impact on its domestic education services. On the other hand, each WTO member nation's suppliers of education services can also enter into international education market to participate in the competition and recruit overseas students.

\subsection{Commercial presence}

With respect to commercial presence, on market access, foreign suppliers of education services can establish joint schools with each WTO member nation's counter-part or wholly-owned schools. They can set up joint schools with one WTO member nation's education service institutions either through introduction of foreign educational resources or in the form of capital investment. With the rapid development of Global economy, the demand for education is increasing steadily. A lot of foreign suppliers of education services have entered WTO member nations' domestic education services market, trying to seize the education market. These institutions are very competitive in terms of software and hardware. And because of their international background, they are very attractive to the students in the age of economic globalization. Each WTO member nation's suppliers of education services will have to face the tough competition and challenge from foreign education service institutions. 


\subsection{Presence of natural person}

With respect to presence of natural person, foreign individuals can enter into each WTO member nation as a natural person to provide education services. And this will not have a serious impact on each WTO member's domestic education services. These foreign individuals will help each WTO member train a large number of high-level professionals, and will play a positive and facilitating role in improving the quality of each WTO member's education services. In the future, there will be a substantial increase in the international flow of individuals among the suppliers of education services of around the world. And the exchange between each WTO member nation's education service institutions and foreign education service institutions will also increase, so each WTO member's education service institutions will become more and more internationalized. On one hand, this will help each WTO member nation's education service institutions employ more talented personnels. On the other hand, the present employees of each WTO member nation's education service institutions will have to face a higher demand on their personal qualities.

\section{End:}

Since joining the WTO, through participating in international competition and the strengthening of international cooperation, all member nations have accelerated the pace of development in economy and foreign trade, promoting the internationalization of educational development. The positive effects of entry into WTO have gradually emerged. Commitments on education services means that each WTO member nation's education services will enter the global market, get a broader space and a new market environment for development, and obtain an opportunity to participate in the competition of globalization in education services. Meanwhile other member nations' education services will make their entry into each member nation's own domestic market, bring about tough competition. Each member nation's education management authorities and education service suppliers should actively face the new situation arising from the commitments on education services strengthen the study and research of WTO rules and actively formulate its related rules.

Modern trade in education services is an important part of trade in services within the framework of WTO, and a newly-emerging and knowledge-based business. The rise of education services has a direct relationship with the in-depth development of the knowledge-based moder economy. Since 1990s, with the unprecedented development and wide application of modern science and technology leaded by information technology, knowledge-based economy has appeared. Modern education had played an increasingly prominent role in the society. Education services are becoming a new business. Western nations have already regarded education services as an industry. They have considered it a very important thing to enter into the markets of education services of developing nations. Many WTO member nations have attached great importance to the use of WTO rules and free trade policies with the purpose of developing their higher education and achieve their own goals and interests.

The invitation of Chinese universities and other suppliers of education services, can foreign individuals enter into China as a natural person to provide education services. And this will not have a serious impact on China's domestic education services. These foreign individuals will help China train a large number of high-level professionals, and will play a positive and facilitating role in improving the quality of China's education services, thus help China develop education services. In the future, there will be a substantial increase in the international flow of individuals among the suppliers of education services of both China and foreign countries. And the exchange between Chinese education service institutions and foreign education service institutions will also increase, so Chinese education service institutions will become more and more internationalized. On one hand, this will help Chinese education service institutions employ more talented personnels. On the other hand, the present employees of Chinese education service institutions will have to face a higher demand on their personal qualities.

\section{References}

Guide to reading the GATS schedules of specific commitments and the list of article II (MFN) exemptions. [Online]Available:http://www.wto.org/english/tratop_e/serv_e/guide1_e.htm (July 18, 2008).

UNDERSTANDING THE WTO: BASICS. Principles of the trading system. [Online] Available: http://www.wto.org/english/theWTO_e/whatis_e/tif_e/fact2_e.htm (October 28, 2008).

UNDERSTANDING THE WTO: THE AGREEMENTS Services: rules for growth and investment. [Online] Available: http://www.wto.org/english/thewto_e/whatis_e/tif_e/agrm6_e.htm (July 18, 2008).

UNDERSTANDING THE WTO: THE ORGANIZATION. Members and Observers. [Online] Available: http://www.wto.org/English/thewto_e/whatis_e/tif_e/org6_e.htm (August 5 2008).

Wu, Zhihui. (2004). Educational Globlization--China'Point of View and Problems. East China Normal University Press. p. 317 . 